\title{
Reply to Letter to the Editor: The Invasive Caribbean Mytilopsis sallei (Bivalvia: Dreissenidae): A Short Review
}

\author{
Koh Siang $\operatorname{Tan}^{1, *}$ and Teresa Tay ${ }^{1}$
}

${ }^{1}$ St. John's Island National Marine Laboratory, Tropical Marine Science Institute, National University of Singapore, 18 Kent Ridge Road, Singapore, 119227

*Corresponding author: tmstanks@nus.edu.sg

SUBMITTED 26 June 2020

ACCEPTED 30 June 2020
ABSTRACT This letter provides a response to the letter concerning “The Invasive Caribbean Mytilopsis sallei (Bivalvia: Dreissenidae): a Short Review" by Tan and Tay in AJSTD 35(1-2): 133-139.

(c) The Author(s) 2020. This article is distributed under a Creative Commons Attribution-ShareAlike 4.0 International license.
We thank the observant reader for the feedback concerning the identification of Mytilopsis sallei (see Marelli 2020), and in particular the relationship between this species and M. adamsi. While we have not had the chance to physically examine the type material of M. adamsi, M. allyneana, and M. zeteki, the original descriptions and illustrations provided of the types of these three species are sufficiently clear to suggest that their morphologies fall within the limits of variability seen in M. sallei. The specific epithet 'sallei' has taxonomic priority over the other three species names. The opening of the Panama Canal in the 1930s may have allowed the transfer of species between the Pacific and Atlantic Oceans, but ships have travelled far and wide across both oceans for at least 300 years before the Canal was constructed. The likelihood of this tenacious and adapt- able species travelling as biofouling on ship hulls across the Straits of Magellan cannot be ruled out. There is also the possibility that the native distribution of Mytilopsis sallei includes both sides of the American isthmus. Our preference is therefore to consider 'sallei' and 'adamsi' as synonyms, until such time when more evidence becomes available concerning their genetic relationships to ascertain their taxonomic status.

\section{REFERENCES}

Marelli D. 2020. Letter to the editor: the invasive Caribbean Mytilopsis sallei (Bivalvia: Dreissenidae): a short review. ASEAN J Sci Technol Dev. 37(2):87. doi:10.29037/ajstd.6 10. 